\title{
初期高温履歴を受けたコンクリートの長期強度発現性 STRENGTH DEVELOPMENT OF CONCRETE CURED UNDER HIGH TEMPERATURE CONDITIONS IN AN EARLY AGE
}

\author{
杉山央*，桝田佳寛** \\ Hisashi SUGIYAMA and Yoshihiro MASUDA
}

\begin{abstract}
The long term strength development of concrete cured under high temperature conditions in an early age was studied. High temperature conditions at curing were planned with systematic varying of the temperature-time factors in the experiment. The strength development of concrete was found to be affected by maximum temperature, pre-curing time, post-curing temperature and heating rate. The time dependence of the effect of curing temperature on the strength development of concrete was indicated. The strength of concrete at a long age strongly depends on the curing temperature at the time of $0-0.5$ day since concrete is mixed up.
\end{abstract}

Keywords : High temperature condition at curing, Strength development, Maximum temperature,

Pre-curing time, Post-curing temperature, Heating rate

高温履歴, 強度発現, 最高温度, 前養生時間, 後養生温度, 温度上昇勾配

\section{1 .はじめに}

近年、鉄筋コンクリート造建築物の品質の向上、施工の合理化を 目的として、これまでの壁や床などの部材に加えて、柱や梁につい てもコンクリートのプレキャスト化が進められている11-81。プレ キャストコンクリートでは、工場での生産効率を上げるため、コン クリート打込み後初期の段階で加熱盖生すなわち人為的に高温を履 歴させる手法を用いて、初期材龄でのコンクリートの強度発現を促 進させている。このため、加熱盖生条件と初期強度発現の関係を明 らかにすることが重要視され9、その後の強度発現に関しては軽視 される傾向にあった。しかし、柱や梁などの構造体として用いられ る場合には、建築物の供用開始以後の強度を把握あるいは推定する ことが必要であり、長期的な強度発現性を明らかにしておくことが 求められる。

一方、鉄筋コンクリート造建築物の高層化・大型化の傾向に伴っ て、高強度のマスコンクリートを使用するケースが増えている。マ スコンクリートの内部では、自己のセメント水和熱が蓄積されるこ とによって温度の上昇が生じ、非定常な高温履歴を受ける。この初 期材龄での高温履歴はマスコンクリートの長期的な強度発現性に影 響を及は寸(0)。マスコンクリートを高強度化した場合、単位セメン ト量が増加するため、さらに顕著な高温履歴および強度発現への影
響が現れ、しばしば問題とされている 11.21.71.81.10\%。しかし、高温履歴 と強度発現に関する定性的な傾向はすでに明らかにされているもの の(0)-14)、定量的あるいは系統的な検討は十分に行われていないの が実状である。

非定常な高温履歴には温度と時間の組み合わせにより、無数の条 件が存在する。従って、コンクリートの強度発現に対して、どのよ うな条件の高温履歴が、どのような影響を、どれだけ及はすのかを 系統的に検討する必要がある。

このような背景のもと、本研究では高温履歴の特性をコンクリー トの練上がりから温度上昇開始までの温度および時間、温度上昇勾 配、最高温度、温度下降勾配、温度下降の終了以後の温度などの種々 の要因（以降、温度履歴要因と記す）を用いてモデル的に表し、そ れぞれの温度履歴要因がコンクリートの材齢1日から 365 日までの 強度発現に及ほす影響を詳細に検討した。

なお、本研究では、強度発現および強度増進の用語を次のように 使い分けた。

·強度発現(性)；材齢 0 (コンクリートの練上がり時)から材齢 $\mathrm{t}$ 日に かけての強度の増加量あるいは増加の傾向

·強度増進(性); 材㱓命 $\mathrm{t}_{1}$ 日から $\mathrm{t}_{2}$ 日までの期間 $\left(\mathrm{t}_{1}<\mathrm{t}_{2}\right)$ の強度の増加 量あるいは増加の傾向
* 建設省建築研究浙第 2 研究部 主任研究員 - I..修

**宇都宫大学:几学部建設学科教授・土博
Senior Research Scientist, Dept. of Building Materials and Components, Building Research Institute, Ministry of Construction, M. Eng.

Prof., Dept. of Architecture and Civil Engineering, Faculty of Engineering, Utsunomiya Univ., Dr. Eng. 


\section{2 . 実験概要}

あらかじめ計画した温度履歴条件をコンクリート供試体に履歴さ せ、所定材齢で圧縮強度試験を行った。

\section{1 使用材料および調合}

セメントにはTable 1に示す性質の普通ポルトランドセメントN1 およびN2を $1 ： 1$ の割合で混合して用いた。骨材には Table 2 に示 す性質の鬼怒川産川砂 $\mathrm{S}$ および岩瀬産砕石 $\mathrm{G}$ を用いた。コンクリー トの調合をTable 3 に示す。なお、高温履歴によってコンクリート中 の空気が熱膨張し、強度に影響を及はすことも考えられる。このた め、消泡剤を用いてコンクリート中の空気量を低減した。

\section{2 コンクリート供試体の形状・寸法および寒生方法}

コンクリート供試体は $\phi 100 \times 200 \mathrm{~mm}$ の円柱形とし、個数は各 条件、各材齢ごとに 3 個ずつとした。実際のプレキャストコンク リート部材やマスコンクリート部材においては、表層部で水分の逸 散が、また、内部で水分の移動が生じており、これらが強度に及ほ す影響も少なくないと考えられる。しかし、本実験では水分の供給 および逸散のほとんどない封かん状態でコンクリート供試体を養生 し、温度履歴と強度発現の関係のみを検討することとした。型枠に はJIS A 5308 付属書 11 に規定するブリキ製の軽量型枠を使用し、 コンクリートを打ち込んだ直後に型朹ごと封かん状態にした。その 後、圧縮強度試験材龄にて開封・脱型した。また、練混ぜバッチ間 の強度差を補正する目的で、それぞれの練混ぜバッチにおいて標準

Table 1 Properties of ordinary portland cements

\begin{tabular}{c|c|c|c|c|c|c|c|c}
\hline Symbol & $\begin{array}{c}\text { Specific } \\
\text { gravity }\end{array}$ & \multirow{2}{*}{$\begin{array}{l}\text { Blaine* } \\
\left(\mathrm{cm}^{2} / \mathrm{g}\right)\end{array}$} & \multicolumn{2}{|c|}{$\begin{array}{c}\text { Setting time } \\
\text { (h-min) }\end{array}$} & \multicolumn{4}{|c}{$\begin{array}{c}\text { Mineral composition } \\
\text { (\%) }\end{array}$} \\
\cline { 4 - 9 } & & & Initial & Final & $\mathrm{C}_{3} \mathrm{~S}$ & $\mathrm{C}_{2} \mathrm{~S}$ & $\mathrm{C}_{3} \mathrm{~A}$ & $\mathrm{C}_{4} \mathrm{AF}$ \\
\hline $\mathrm{N} 1$ & 3.16 & 3330 & $2-15$ & $3-15$ & 53.7 & 20.9 & 8.6 & 8.8 \\
$\mathrm{~N} 2$ & 3.15 & 3250 & $2-25$ & $3-58$ & 52.1 & 22.1 & 9.5 & 8.2 \\
\hline
\end{tabular}

* Blaine specific surface area

Table 2 Properties of aggregates

\begin{tabular}{c|c|c|c|c|c|c}
\hline & Symbol & Kind & $\begin{array}{c}\text { Max. size } \\
(\mathrm{mm})\end{array}$ & $\begin{array}{c}\text { Specific } \\
\text { gravity* }\end{array}$ & $\begin{array}{c}\text { Adsorption } \\
(\%)\end{array}$ & $\begin{array}{c}\text { Fineness } \\
\text { modulus }\end{array}$ \\
\hline Fine & $\mathrm{S}$ & River sand & 5 & 2.58 & 2.07 & 2.88 \\
Coarse & $\mathrm{G}$ & Crushed stone & 20 & 2.66 & 0.68 & 6.64 \\
\hline
\end{tabular}

* At saturated surface-dried condition

Table 3 Mix proportion of concrete

\begin{tabular}{|c|c|c|c|c|c|c|c|c|}
\hline \multirow{2}{*}{$\begin{array}{l}\text { W/C } \\
(\%)\end{array}$} & \multirow{2}{*}{$\begin{array}{l}\text { Slump } \\
(\mathrm{cm})\end{array}$} & \multirow{2}{*}{$\begin{array}{c}\text { Air } \\
\text { content } \\
(\%)\end{array}$} & \multicolumn{4}{|c|}{$\begin{array}{l}\text { Unit content } \\
\left(\mathrm{kg} / \mathrm{m}^{3}\right)\end{array}$} & \multicolumn{2}{|c|}{$\begin{array}{l}\text { Admixture* } \\
(\mathrm{C} \times \%)\end{array}$} \\
\hline & & & W & $\mathrm{C}$ & $\mathrm{S}$ & G & Ad1 & $\overline{\mathrm{Ad} 2}$ \\
\hline 40 & $8.0 \pm 1.5$ & $1.0 \pm 0.7$ & 160 & 400 & 8 & 97 & & 0.1 \\
\hline
\end{tabular}

* Ad1; Water reducing agent, Ad2; Air reducing agent

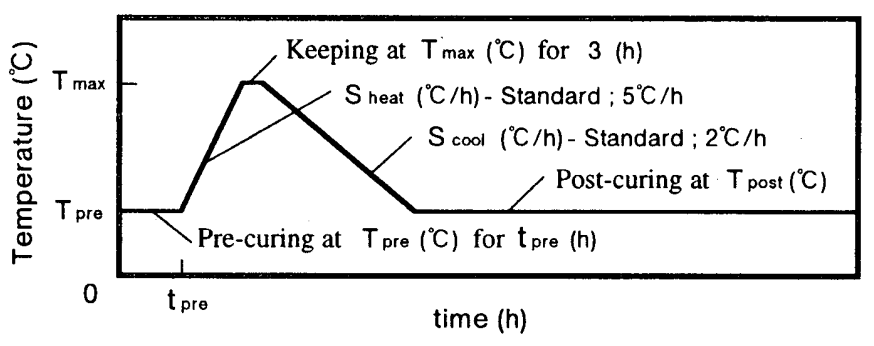

Fig.1 High temperature pattern at curing
養生のコンクリート供試体も作製した。

\section{3 温度履歴条件}

本実験では、初期材龄での高温履歴をFig.1 に示す高温履歴パ ターンにモデル化して、温度履歴条件を計画した。なお、Fig.1の中 で、Tpreはコンクリートの練上がりから温度上昇開始までの期間の 温度 (以降、前養生温度と記す)、 $\mathrm{t}$ re はコンクリートの練上がりか ら温度上昇開始までの時間（以降、前養生時間と記す）、 $T \max$ は最 高温度、 $\mathrm{T}_{\text {post }}$ は温度下降の䅂了以後の温度 (以降、後養生温度と記 す)、S heatは温度上昇勾配、S cool は温度下降勾配である。温度上昇 勾配の標準值は $5^{\circ} \mathrm{C} / \mathrm{h}$ に、また、温度下降勾配の標準値は $2^{\circ} \mathrm{C} / \mathrm{h}$ に 設定した。Fig.1の高温履歴パターンを基にそれぞれ温度履歴要因を 設定して、2シリーズ、計 27 パターンの温度履歴条件を計画した。 温度履歴条件のシリーズ A Fig.2に、また、シリーズ B をFig.3に 示す。

既往の研究 101.131.141では、各種の温度履歴要因の中でコンクリート の強度発現に最も大きな影響を及はす要因は最高温度であることが 指摘されている。そこで、シリーズ A では最高温度、前養生時間、 および最高温度と前盖生時間の組み合わせによる影響を検討した。 すなわち、最高温度 $90,75,60,45^{\circ} \mathrm{C}$ のれれぞれの場合について、 前養生時間を $0.5 \mathrm{~h}, 3 \mathrm{~h}, 24 \mathrm{~h}$ に設定した。一方、シリーズBでは、I)
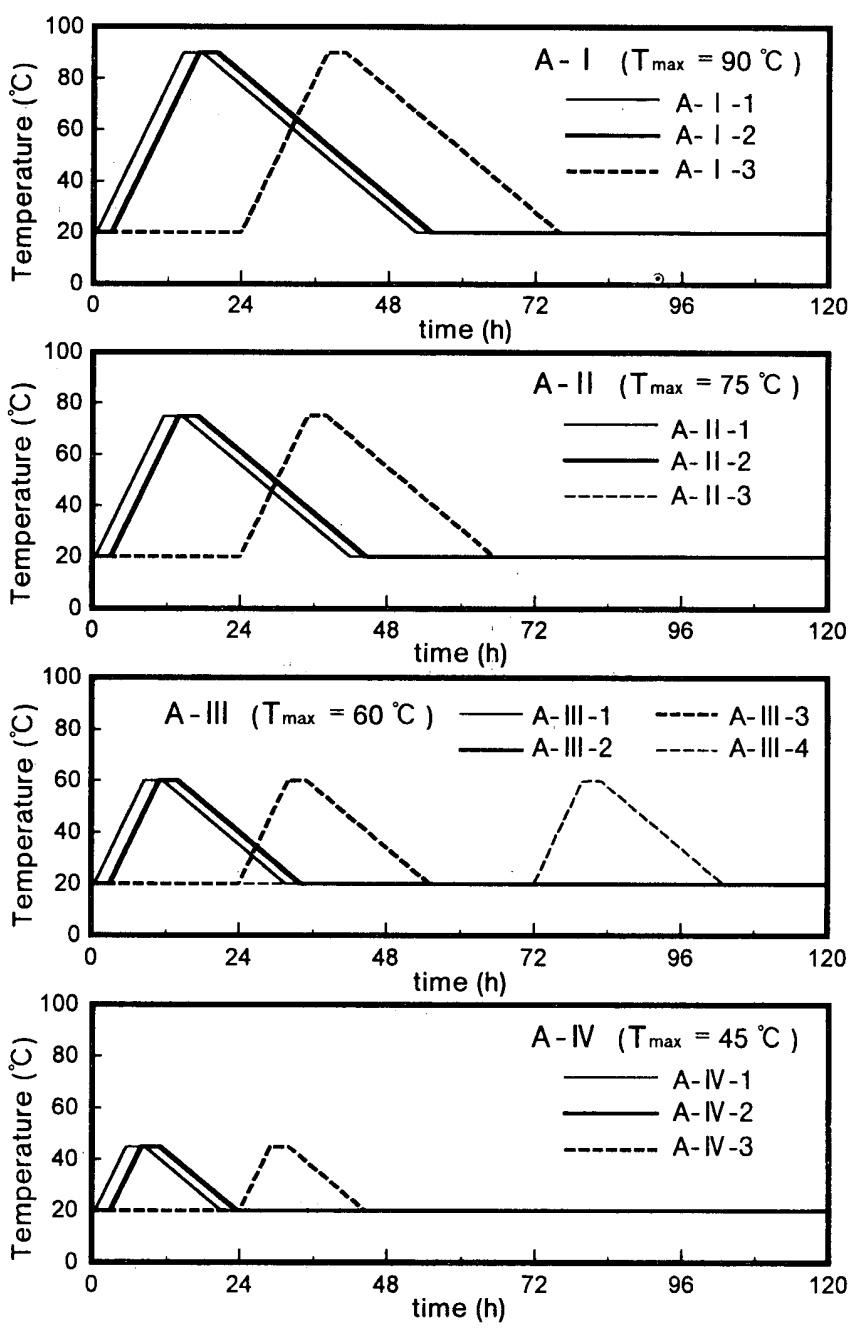

Fig.2 Temperature-time conditions ( Series A) 


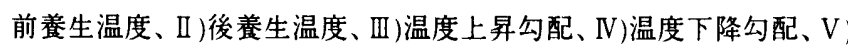
前養生温度・最高温度・後養生温度の組み合わせの影響を検討した。 なお、シリーズ Bでは、すべての温度履歴条件に共通して前養生時 間を $3 \mathrm{~h}$ とした。これらに加えて、比較のため、20号一定の温度条 件（封かん盖生）を計画した。

実験では、計画した温度でコンクリートが練り上がるように、練 混ぜの 24 時間前から使用材料およびミキサを所定の温度に保持し、 所定の温度の実験室でコンクリートの練混ぜおよびコンクリート供 試体の成形を行った。コンクリート供試体成形以後の温度の制御は、 コンクリート供試体の中心部が計画した温度履歴条件と同じ温度を 履歴するように加熱養生槽内の温度を調節することで行った。なお、 温度㠅歴の開始時間はコンクリートの練上がり時とした。コンク リート供試体が実際に履歴した温度と計画した温度履歴条件との差 は、すべての温度履歴条件を通じて、士 $3^{\circ} \mathrm{C} の$ 範囲内であった。
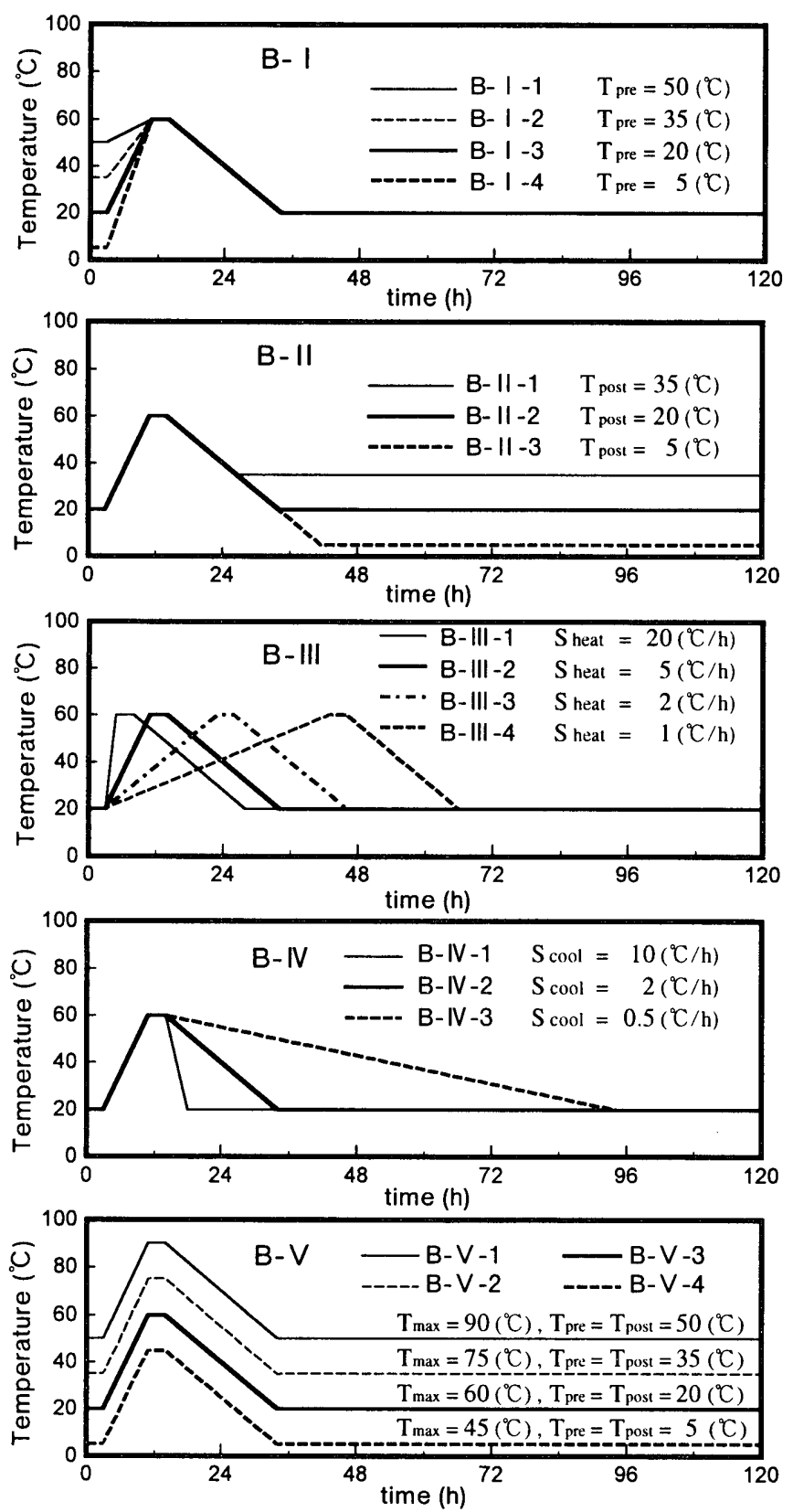

Fig.3 Temperature-time conditions ( Series B )

\section{4 圧縮強度試験}

材㱓 1，3，7，28，91 および 365 日において圧縮強度試験を 行った。試験方法はJIS A 1108 に従った。

\section{3、実験結果および考察}

\section{1 最高温度および前意生時間と強度発現の関係}

シリーズAの強度発現をFig.4に示す。なお、Fig.4には、高温履 歴を受けたコンクリート（以降、高温履歴コンクリートと略記）と ともに、 $20^{\circ} \mathrm{C}$ 一定の温度条件で封かん養生したコンクリート（以 降、20S コンクリートと略記）の強度発現も示した。前養生時間が $0.5 \mathrm{~h}$ および $3 \mathrm{~h}$ の高温履歴コンクリートでは、20S コンクリートに 比べて、材齢 1 日までの強度発現が著しい。しかし、材澮 1 日以降 の強度增進は緩やかとなり、7 日で20Sコンクリートの強度を下回 ク、その後は材齢の経過とともに20Sコンクリートとの強度の差が 大きくなる。前養生時間が $24 \mathrm{~h}$ の高温履歴コンクリートでは、20S コンクリートに比べて、材齢1 日から 3 日までの強度増進が著しい。 しかし、3 日以降の強度增進は緩やかとなり、28 日で $20 \mathrm{~S}$ コンク リートの強度を下回る。

高温履歴コンクリートの強度発現を定量的に検討するため、(1)式 に示す強度発現率を定義した。なお、20S コンクリートの場合、(1) 式の $F_{\mathrm{t}}$ には(2)式に示すものを用いた。また、高温履歷コンクリー トの場合、練上がり温度が $20^{\circ} \mathrm{C}$ 条件では(1)式の F、に(3)式に示 すものを用い、練上がり温度が $20^{\circ} \mathrm{C}$ 以外の条件では(1)式のF に に(4) 式に示すものを用いた。
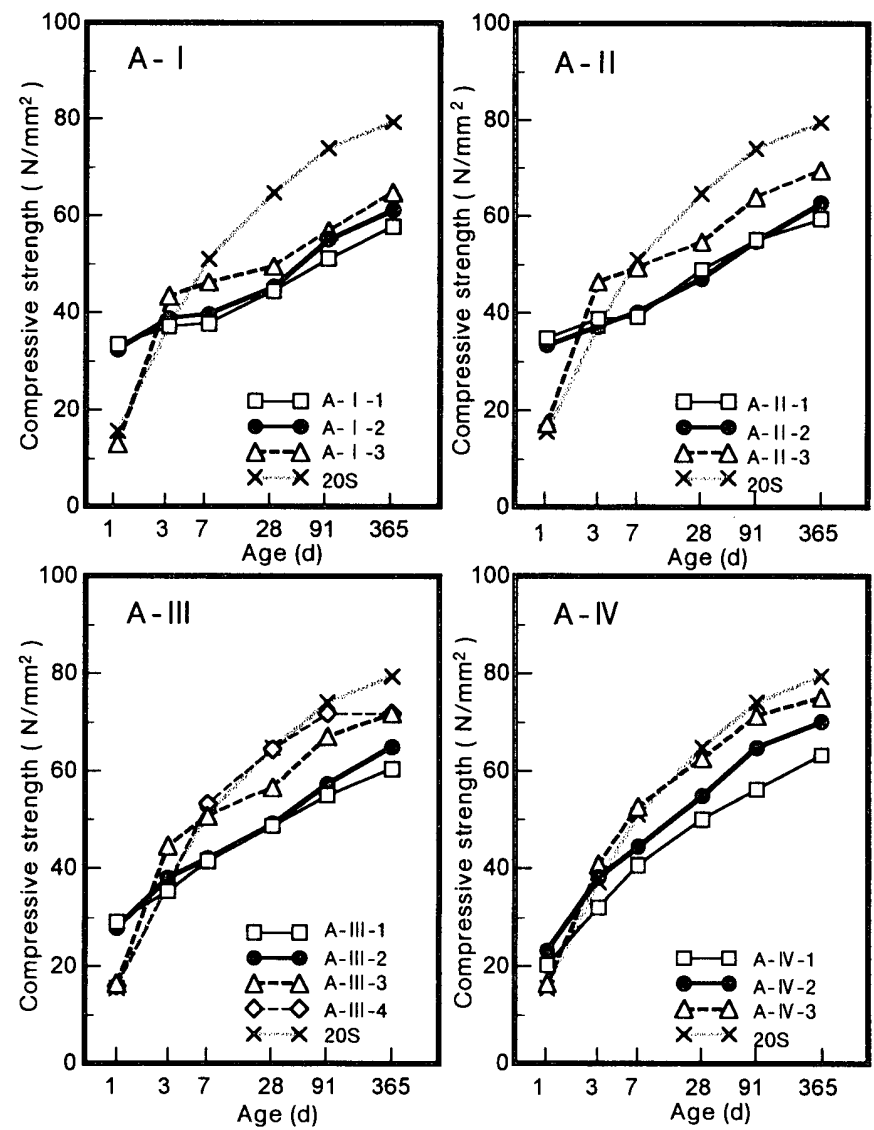

Fig.4 Strength development of concrete ( Series A ) 


$$
f_{\mathrm{t}}=\frac{F_{\mathrm{t}}}{20 \mathrm{~S} F_{365}} \times 100
$$

ただし、20Sコンクリートの場合、

$F_{\mathrm{t}}={ }_{20 \mathrm{~S}} F_{\mathrm{t}}$

高温履歴コンクリートの場合、

$$
\begin{array}{ll}
F_{\mathrm{t}}=\mathrm{h}_{\mathrm{h}} F_{\mathrm{t}} \times \frac{20 \mathrm{w}(20 \mathrm{~s}) F_{\mathrm{t}}}{20 \mathrm{w}(\mathrm{h}) F_{\mathrm{t}}} & \text { (練.上がり温度 }=20^{\circ} \mathrm{C} \text { ) } \\
F_{\mathrm{t}}=\mathrm{h}_{\mathrm{h}} F_{\mathrm{t}} & \text { (練上がり温度 } \neq 20^{\circ} \mathrm{C} \text { ) }
\end{array}
$$

\section{ここに、 $f_{\mathrm{t}}$ ：材齢 $\mathrm{t}$ 日における強度発現率 $(\%)$}

${ }_{20 S} F 365 ： 20 S$ コンクリートの材舲 365 日における強度 $\left(\mathrm{N} / \mathrm{mm}^{2}\right)$ ${ }_{20 \mathrm{~S}} F_{\mathrm{t}}: 20 \mathrm{~S}$ コンクリートの材戟 $\mathrm{t}$ 日における強度 $\left(\mathrm{N} / \mathrm{mm}^{2}\right)$ $\mathrm{h} F \mathrm{t}$ : 高温履歷コンクリートの材齢 $\mathrm{t}$ 日に扔ける強度 $\left(\mathrm{N} / \mathrm{mm}^{2}\right)$ $20 \mathrm{~W}(20 \mathrm{~s}) F_{\mathrm{t}} ： 20 \mathrm{~S}$ コンクリートと同じ練混ぜバッチより採取した 標準養生コンクリートの材咸 $\mathrm{t}$ 日に扔ける強度 $\left(\mathrm{N} / \mathrm{mm}^{2}\right)$ ${ }^{20 \mathrm{w}(\mathrm{h})} F_{\mathrm{t}}$ ：高温履歴コンクリートと同じ練混ぜバッチより採取した 標準養生コンクリートの材龄 $\mathrm{t}$ 日における強度 $\left(\mathrm{N} / \mathrm{mm}^{2}\right)$

(1)式の強度発現率では、20Sコンクリートの材龄365日の強度を 基準の強度としている。ただし、この基準強度はあくまでも終局強 度ではないため、温度履歴条件によっては (1)式の強度発現率が 100\%を超える場合も考えられる。(3)式では、材料の計量誤差などに よって発生する練混ぜバッチ間の強度差を補正する目的で、各々の 練混ぜバッチにおける標準養生コンクリートの強度を用いて、20S コンクリートの強度を基準とした強度の補正を行っている。ただし、
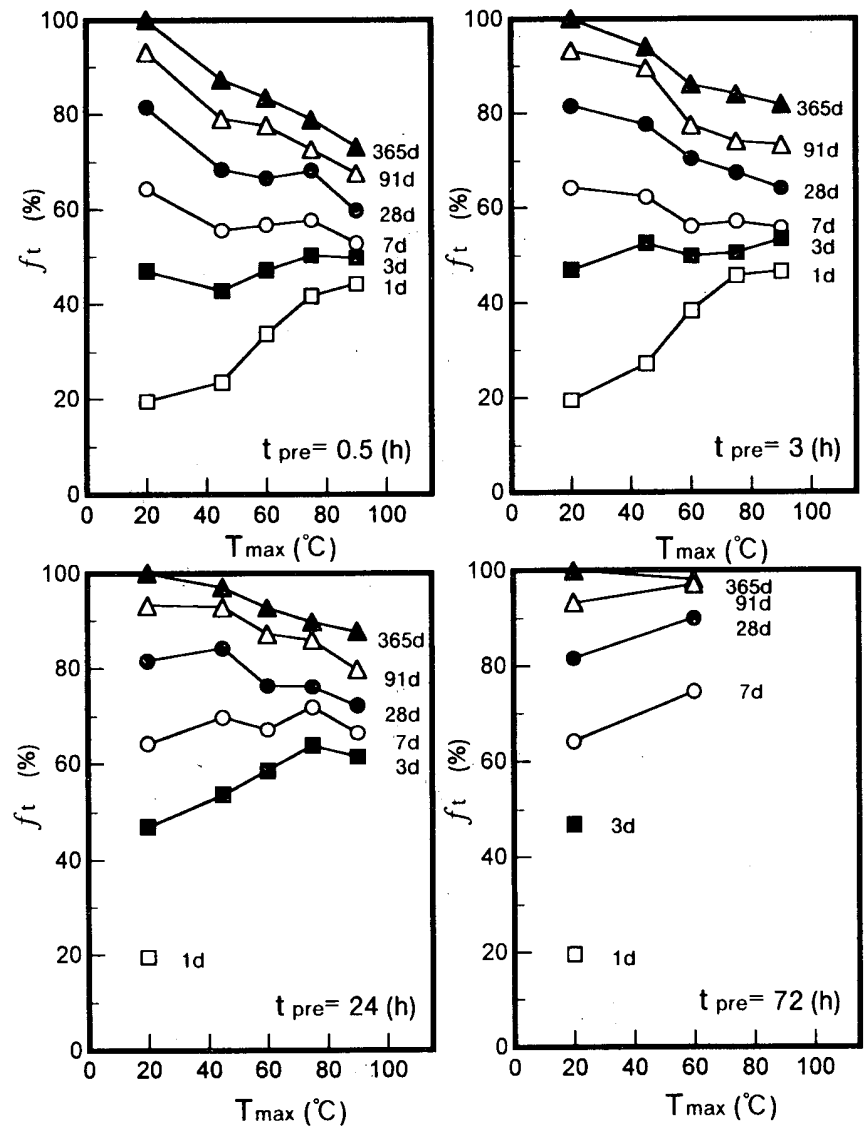

Fig.5 Relation between maximum temperature and the degree of strength development ( Series A )
B- I -1、B- I - 2、B- I -4、B-V-1、B-V-2 および B-V -4では、

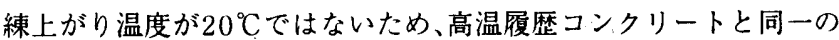
練混ぜバッチから適切な標準養生コンクリートを得ることができな かった。そこで、(4)式に示すように練混ぜバッチ間の強度差の補正 は行わず、(1)式における $F$ 、として、n $F$ 、の值をそのまま用いること とした。

各材㱓における最高温度と強度発現率の関係を前養生時間ごとに Fig.5に示す。なお、Fig.5の中で最高温度 $20^{\circ} \mathrm{C}$ の值は、20Sコンク リートの強度発現率である。最高温度の違いにより高温履歷コンク リートの強度発現率が大きく異なることが明らかである。

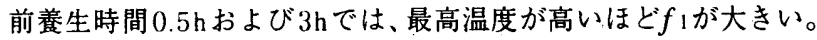
f1を比較すると、20S コンクリートで $20 \%$ を示したのに対して、前 養生時間 $0.5 \mathrm{~h}$ の場合には、最高温度 $45^{\circ} \mathrm{C} て ゙ 23 \% 、 60^{\circ} \mathrm{C} て ゙ 3 \% 、 75$ ${ }^{\circ} \mathrm{C}$ で $42 \% 、 90^{\circ} \mathrm{C} て ゙ 44 \%$ を示した。また、前養生時間 $3 \mathrm{~h}$ の場合に は、最高温度 $45{ }^{\circ} \mathrm{C}$ で $27 \% 、 60^{\circ} \mathrm{C}$ で $38 \% 、 75^{\circ} \mathrm{C}$ で $46 \% 、 90^{\circ} \mathrm{C}$ で 47 \%を示した。材齢 1 日以降の強度発現率の増加は最高温度が高いほ ど小さくなり、3 日から 7 日にかけては最高温度によらず大差ない 強度発現率を示した。材齢 28 日以降では、最高温度が高いほど強 度発現率が小さくなる。 $f 365$ を比較すると、20Sコンクリートの 100 $\%$ に対して、前盖生時間 $0.5 \mathrm{~h}$ の場合には、最高温度 $45^{\circ} \mathrm{C} て ゙ ~ 87 \%$ 、 $60^{\circ} \mathrm{C}$ で $84 \% 、 75^{\circ} \mathrm{C} て ゙ 79 \% 、 90^{\circ} \mathrm{C}$ で $73 \%$ を示した。すなわち、最 高温度の違い $\left(20 \sim 90^{\circ} \mathrm{C}\right.$ 範囲)により、材齿 365 日の強度発現 率には $27 \%$ の差が生じた。また、前養生時間 $3 \mathrm{~h}$ の場合には、最高 温度 $45^{\circ} \mathrm{C}$ で $94 \% 、 60^{\circ} \mathrm{C}$ で $86 \% 、 75^{\circ} \mathrm{C}$ で $84 \% 、 90^{\circ} \mathrm{C}$ で $82 \%$ を示
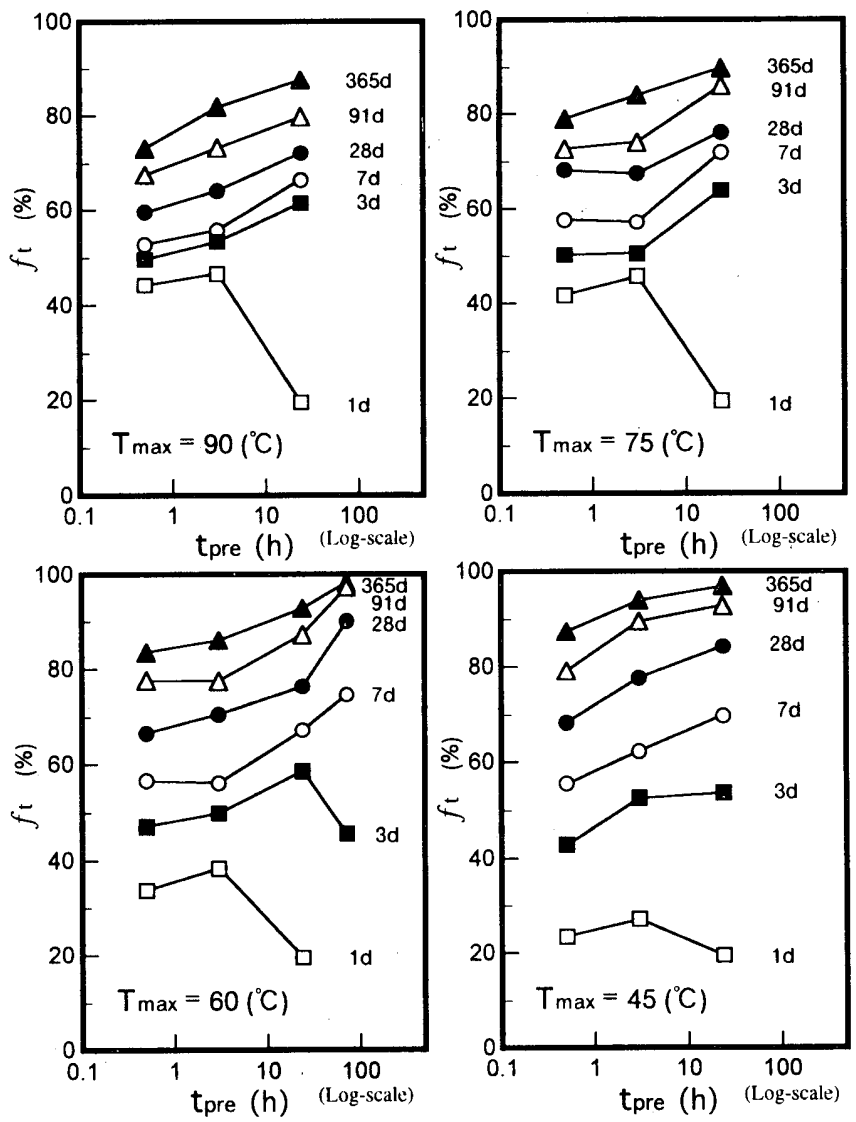

Fig.6 Relation between pre-curing time and the degree of strength development ( Series A ) 
した。すなわち、最高温度の違いにより、材齢 365 日の強度発現率 には $18 \%$ 差が生じた。

前養生時間 $24 \mathrm{~h}$ では、最高温度が高いほど $f 3$ が大きい。しかし、 材澮 3 日以降の強度発現率の増加は最高温度が高いほど小さくなり、 材齢91日以降では、最高温度が高いほど強度発現率が小さくなる。 $f 365$ を比較すると、最高温度 $45^{\circ} \mathrm{C}$ で $97 \% 、 60^{\circ} \mathrm{C}$ で $93 \% 、 75^{\circ} \mathrm{C}$ で $90 \% 、 90^{\circ} \mathrm{C}$ で $88 \%$ を示した。すなわち、最高温度の違いにより、材 齢 365 日の強度発現率には $12 \%$ 差が生じた。前養生時間 $72 \mathrm{~h}$ の 高温履歴コンクリートでは、材㱓 3 日から 91 日にかけての強度発 現率が $20 S$ コンクリートよりも大きく、 $f 365$ は $20 S$ コンクリートと 大差ない $98 \%$ を示した。すなわち、 $72 \mathrm{~h}$ 以降の高温履歴は長期的な 強度発現を著しく停滞させることはない。

各材澮における前養生時間と強度発現率の関係を最高温度ごとに Fig.6に示す。同じ最高温度であっても、前養生時間が短い高温履歴 コンクリートほど、すなわち、早期に高温履歴を受けたコンクリー トほど長期材齢での強度発現率が小さい。また、前養生時間が異な ることによる強度発現率の差異は最高温度が高い場合ほど著しい。 前盖生時間 $0.5 \mathrm{~h}$ と $24 \mathrm{~h}$ の場合について $f 365$ を比較すると、その差 は最高温度 $45^{\circ} \mathrm{C}$ で $10 \% 、 60^{\circ} \mathrm{C}$ で $9 \% 、 75^{\circ} \mathrm{C}$ で $11 \% 、 90{ }^{\circ} \mathrm{C}$ で $14 \%$ であった。一方、 $f_{1}$ を比較すると、前養生時間 $0.5 \mathrm{~h}$ の方が $3 \mathrm{~h}$ の場 合よりも小さい。すなわち、コンクリート打ち込み直後の高温履歷 は、初期強度発現に対しても、有利に働かないことがわかる。

以上より、最高温度は高温履歴コンクリートの強度発現に大きな 影響を及ほす温度履歴要因であるが、同じ最高温度であっても前養 生時間が異なると、すなわち、最高温度を履歴する夕イミングが異 なると、コンクリートの強度発現は大きく異なることが明らかであ る。既往の研究では、高温履歴と強度発現の関係を検討する際に、 高温履歷の特性を表すパラメータとして最高温度を用いる場合が多

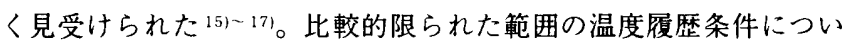
ては、最高温度を目安として強度発現の評価・予測を行っても大き な誤差が生じないと考えられる。しかし、広い範囲の温度履歴条件 についても強度発現の評価・予測を可能とするためには、最高温度 以外の温度履歴要因を考慮する必要がある。

\section{2 温度履歴要因と強度発現の関係}

シリーズ B の強度発現をFig.7に示す。また、各材㱓における温 度履歴要因と強度発現率の関係を Fig.8に示す。なお、B-Vは前養 生温度、最高温度および後養生温度のそれぞれの要因を変えたシ リーズであるが、Fig.8では最高温度との関係を示した。

B-Iでは、前養生温度が高いほど材齢 1 日での強度発現率は大き いが、7 日以降の強度発現率は小さくなる傾向が認められる。しか し、前養生温度の違いによる強度発現率の差異は小さい。前養生温 度の違い $\left(5 \sim 50{ }^{\circ} \mathrm{C}\right.$ 範囲)により生じた強度発現率の差は、材齢 1 日で $5 \% 、 365$ 日で $6 \%$ であった。

B- II では、後盖生温度が高いほど 3 日以降の材齢での強度発現率 が大きくなる傾向が認められ、この傾向は材齢の経過とともに著し くなる。すなわち、後養生温度が高いと長期材齢での強度增進を促 進させ、後養生温度が低いと長期材龄での強度增進を停滞させるこ とがわかる。後養生温度の違い $\left(5 \sim 35^{\circ} \mathrm{C}\right.$ の範囲)により生じた強 度発現率の差は、材㱓 3 日で $6 \% 、 365$ 日で $18 \%$ であった。

B· III では、温度上昇勾配が大きいほど材齢 3 日以降の強度発現率
が小さくなる傾向が認められる。特に、B· II -1（温度上昇勾配 20 ${ }^{\circ} \mathrm{C} / \mathrm{h}$ ) ではこの傾向が著しく、材㱓 365 日の強度発現率は $74 \%$ で あった。また、B- III - 1 は温度上昇勾配が $5{ }^{\circ} \mathrm{C} / \mathrm{h}$ 以下の条件に比べ て、材齢 1 日での強度発現率も小さい。すなわち、コンクリートの 練上がりから 0.5 日までの期間に急激な温度上昇を伴った高温履歴 を受けると、材齢 1 日の段階で強度発現の停滞傾向が現れることが わかる。温度上昇勾配の違い $\left(1 \sim 20^{\circ} \mathrm{C} / \mathrm{h}\right.$ の範囲)により生じた強 度発現率の差は、材㱓 365 日で $15 \%$ であった。

B-IVでは、温度下降勾配が大きいほど、すなわち早期に $20^{\circ} \mathrm{C} ま$ で降温した条件ほど材齢 1 日での強度発現率は小さいが、28日以降 の強度発現率が大きくなる傾向が認められる。しかし、温度下降勾 配の違いによる強度発現率の差異は小さい。温度下降勾配の違い $\left(0.5 \sim 10^{\circ} \mathrm{C} / \mathrm{h}\right.$ の範囲) により生じた強度発現率の差は、材䍅 365
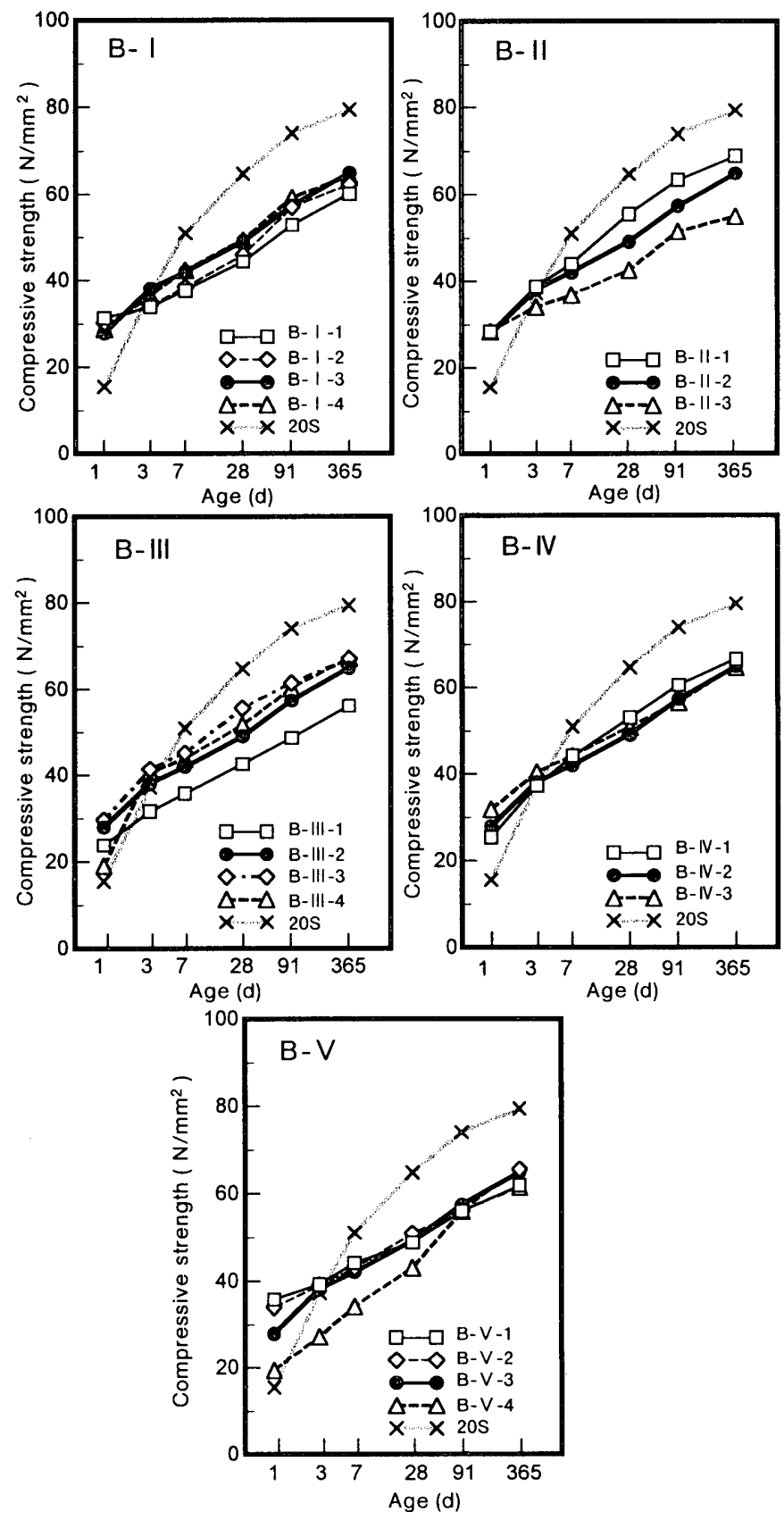

Fig.7 Strength development of concrete ( Series B ) 

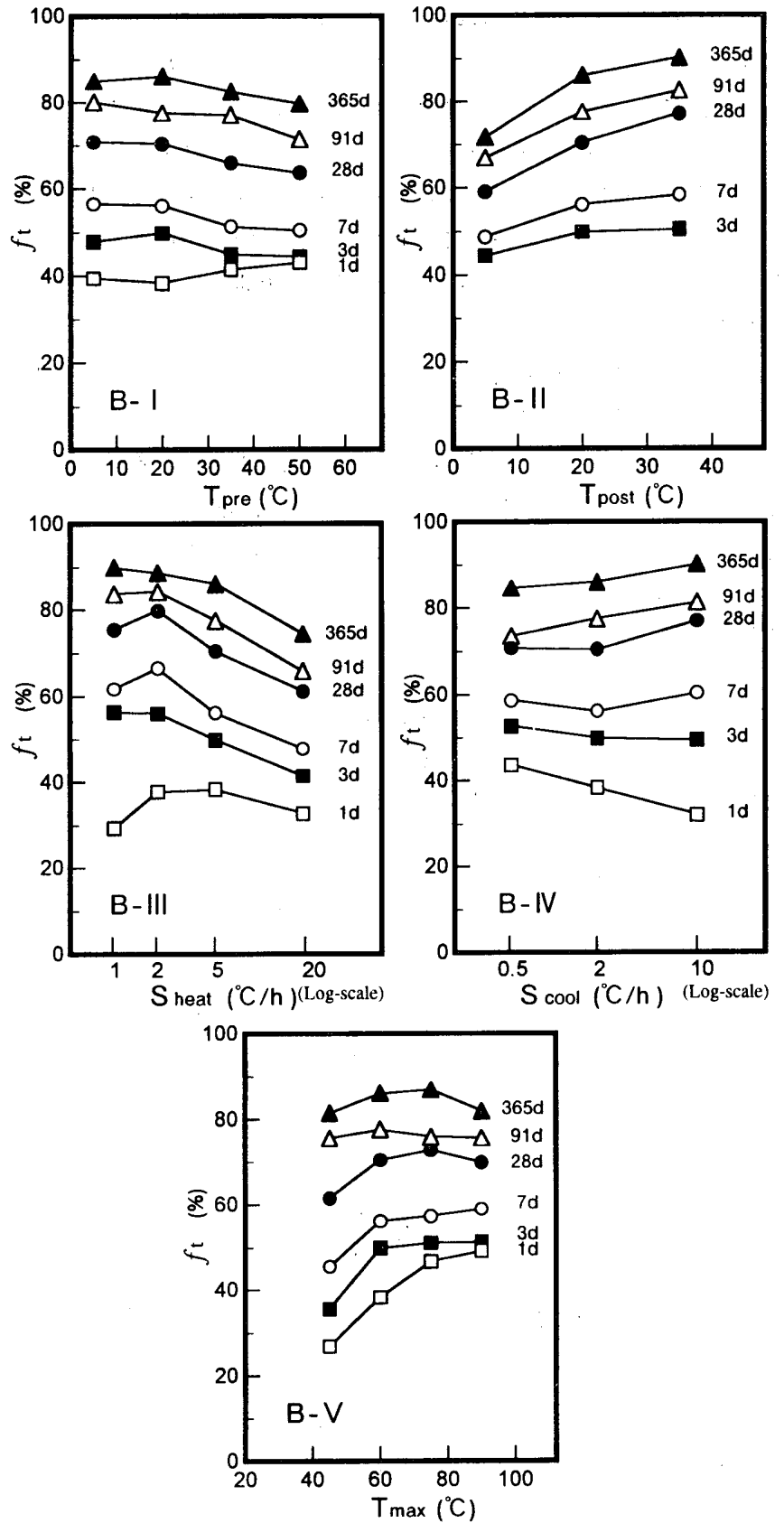

Fig.8 Relation between the temperature-time factors and the degree of strength development ( Series B )

日で6\%であった。

B.Vでは、材齢 91 日および 365 日において、温度履歴条件の違 いによる強度発現率の差異が小さい。この理由としては、B-V-1お よび B-V -2では最高温度が高いことによって長期材齢での強度増 進が停滞する傾向と、後養生温度が高いことによって長期材龄での 強度增進が促進される傾向とが相まって、長期材齢で B.V - 3 と大 差ない強度発現率を示したと考えられる。また、B・V-4では後養生 温度が低いため、材龄 3 日以降の強度增進が停滞したと考えられる。 3.3 温度履歴要因が強度発現に及ぼす影響についての定量的な検討

3.1 および 3.2 の結果より、高温履歴コンクリートの強度発現を 検討するには最高温度などの単一のパラメー夕と関連づけることは 難しく、高温履歴の特性を表す複数の温度履歴要因がパラメータと して必要であること、また、それぞれの温度履歴要因によって強度
発現に及ほす影響の大きさは異なることが明らかになった。そこで、 各々の温度履歴要因が高温履歴コンクリートの強度発現に及ほす影 響の定量的な検討を統計解析の手法を用いて行った。ここでは、 20Sコンクリートの温度履歴条件および強度発現率を基準とした (5) 式および(6)式を定義し、各材㱓での高温履歷コンクリートと20Sコ ンクリートの強度発現率の差 $\Delta f \mathrm{t}$ と温度履歷要因との関係を前進ス テップワイズ回帰分析を用いて数值化した。

$$
\begin{aligned}
f_{\mathrm{t}}= & { }_{20 \mathrm{~s}} f_{\mathrm{t}}+\Delta f_{\mathrm{t}} \\
\Delta f_{\mathrm{t}}= & \mathrm{a} 1 \times\left(\mathrm{T}_{\text {pre }}-20\right)+\mathrm{a} 2 \times\left(\mathrm{T}_{\max }-20\right)+\mathrm{a} 3 \times\left(\mathrm{T}_{\text {post }}-20\right) \\
& +\mathrm{a} 4 \times \mathrm{S}_{\text {heat }}+\mathrm{a} 5 \times \mathrm{S} \text { cool }+\mathrm{a} 6 \times \mathrm{t}_{\text {pre }}
\end{aligned}
$$

ここに、 $f_{\mathrm{t}}$ : 高温履歷コンクリートの材澮 20s $f_{\mathrm{t}}: 20 \mathrm{~S}$ コンクリートの材龄 $\mathrm{t}$ 日に扔ける強度発現率 (\%)

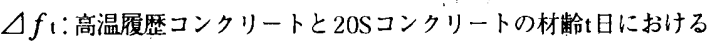
強度発現率の差 $(\%)$

$\mathrm{T}_{\mathrm{pre}}$ : 前盖生温度 $\left({ }^{\circ} \mathrm{C}\right)$

$\mathrm{T}_{\max }$ : 最高温度 $\left({ }^{\circ} \mathrm{C}\right)$

$\mathrm{T}_{\text {post }}$ ：後養生温度 $\left({ }^{\circ} \mathrm{C}\right)$

$\mathrm{S}_{\text {heat }}$ : 温度上昇勾配 $\left({ }^{\circ} \mathrm{C} / \mathrm{h}\right)$

$\mathrm{S}_{\text {cool }}$ : 温度下降勾配 $\left({ }^{\circ} \mathrm{C} / \mathrm{h}\right)$

$t_{\text {pre }}$ ：前養生時間 $(h)$

a1, a2, a3, a4, a5, a6: 偏回㷌倸数

前進ステップワイズ回帰分析とは、各ステップごとに分析を行 い、指定した F-in 值以上で最も大きな $\mathrm{F}$ 值を持つ変数を回帰方程式 に取り込み、回帰方程式に含まれている变数の中で指定したF-out 值よりも小さなF值を持つ変数を回帰方程式から削除する手法であ る。従って、 $\Delta f \mathrm{t}$ と密接な関係にある温度履歴要因は早いステップ 段階で回帰方程式に取り込まれ、 $\Delta f \mathrm{t}$ にあまり関係のない温度履歴 要因は回帰方程式に取り込まれない。ここでは、F-in值として 4.0、 F·out值として 2.0 を設定した。

前進ステップワイズ回㷌分析の結果をTable 4 に示す。なお、Table 4 中の( )内の数值は標準化回帰係数である。標準化回帰係数とは、 データをすべて平均 0 ，分散 1 に基準化し、それを基に計算した回 帰係数であり、標準化回帰係数の絶対值を比べることで $\Delta f \mathrm{t}$ に対す る各々の温度履歴要因の貢献度（影響の大きさ）を比較することが できる。

$\Delta f$ にについては、最高温度が最も密接な関係にあり、卓越した影 響を及ほしている。最高温度が $1{ }^{\circ} \mathrm{C}$ 高いと、材㱓1 日での強度発現 率は約 $0.4 \%$ 大きくなる。次いで、前養生時間が密接な関係にあり、 前盖生時間が $0.5 \mathrm{~h}$ の場合のように温度上昇の開始時期が早いと、材 歯 1 日での強度発現率は小さくなる。また、温度上昇勾配および温 度下降勾配の影響は小さい。

$\Delta f_{3}$ については、前養生時間および後養生温度が取り込まれた が、回帰方程式の奇与率が 0.62 と低く、密接な関係は認められない。

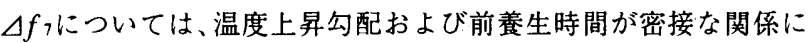
あり、大きな影響を及ほしている。前養生時間が長いほど、すなわ ち、高温を履歴する時期が遅いほど材龄 7 日の強度発現率は大きく なる。また、後養生温度が高いほど材㱓 7 日の強度発現率は大きく なる。他方、温度上昇勾配、前養生温度および最高温度が大きいほ 
Table 4 Results of stepwise regression analysis

\begin{tabular}{|c|c|c|c|c|c|c|c|c|c|}
\hline \multirow[t]{2}{*}{$\Delta f_{\mathrm{t}}$} & \multirow[t]{2}{*}{ Step } & \multicolumn{6}{|c|}{ Coefficient a } & \multirow{2}{*}{$\begin{array}{c}\text { Multiple } \\
\mathbf{R}^{2}\end{array}$} & \multirow{2}{*}{$\begin{array}{c}\mathrm{R}^{2} \\
\text { change }\end{array}$} \\
\hline & & $T_{\text {pre }}$ & $T_{\max }$ & $T_{\text {post }}$ & $S_{\text {heat }}$ & $S_{\text {cool }}$ & $t$ pre & & \\
\hline \multirow{5}{*}{$\Delta f_{1}$} & 1 & - & 0.43 & - & - & - & - & 0.963 & - \\
\hline & 2 & - & 0.37 & - & - & - & 1.11 & 0.969 & 0.006 \\
\hline & 3 & - & 0.40 & - & -0.44 & - & 1.46 & 0.976 & 0.007 \\
\hline & 4 & - & 0.42 & - & -0.39 & -0.75 & 1.66 & 0.981 & 0.005 \\
\hline & & - & $(0.96)$ & - & $(-0.12)$ & $(-0.11)$ & $(0.23)$ & & \\
\hline \multirow{3}{*}{$\Delta f_{3}$} & 1 & - & - & - & - & - & 0.53 & 0.550 & - \\
\hline & 2 & - & - & 0.23 & - & - & 0.52 & 0.624 & 0.074 \\
\hline & & - & - & $(0.27)$ & - & - & $(0.73)$ & & \\
\hline \multirow{6}{*}{$\Delta f_{7}$} & 1 & - & - & - & -0.94 & - & - & 0.393 & - \\
\hline & 2 & - & - & - & -1.26 & - & 0.28 & 0.629 & 0.236 \\
\hline & 3 & - & -0.08 & - & -0.80 & - & 0.32 & 0.686 & 0.057 \\
\hline & 4 & - & -0.11 & 0.28 & -0.70 & - & 0.34 & 0.747 & 0.061 \\
\hline & 5 & -0.28 & -0.08 & 0.47 & -0.86 & - & 0.33 & 0.803 & 0.056 \\
\hline & & $(-0.31)$ & $(-0.41)$ & $(0.43)$ & $(-0.57)$ & - & $(0.61)$ & & \\
\hline \multirow{6}{*}{$\Delta f_{28}$} & 1 & - & -0.23 & - & - & - & - & 0.676 & - \\
\hline & 2 & - & -0.28 & - & - & - & 0.30 & 0.799 & 0.123 \\
\hline & 3 & - & -0.30 & 0.46 & - & - & 0.33 & 0.881 & 0.082 \\
\hline & 4 & - & -0.24 & 0.42 & -0.57 & - & 0.33 & 0.906 & 0.025 \\
\hline & 5 & -0.29 & -0.21 & 0.61 & -0.73 & - & 0.32 & 0.935 & 0.029 \\
\hline & & $(-0.23)$ & $(-0.78)$ & $(0.40)$ & $(-0.34)$ & - & $(0.43)$ & & \\
\hline \multirow{6}{*}{$\Delta f_{91}$} & 1 & - & -0.31 & - & - & - & - & 0.806 & - \\
\hline & 2 & - & -0.37 & - & - & - & 0.31 & 0.887 & 0.081 \\
\hline & 3 & - & -0.28 & - & -0.87 & - & 0.32 & 0.923 & 0.036 \\
\hline & 4 & - & -0.31 & 0.32 & -0.77 & - & 0.34 & 0.947 & 0.024 \\
\hline & 5 & -0.31 & -0.28 & 0.52 & -0.94 & - & 0.33 & 0.967 & 0.021 \\
\hline & & $(-0.19)$ & $(-0.79)$ & $(0.26)$ & $(-0.35)$ & - & $(0.34)$ & & \\
\hline \multirow{6}{*}{$\Delta f_{365}$} & 1 & - & -0.31 & - & - & - & - & 0.837 & - \\
\hline & 2 & - & -0.35 & - & - & - & 0.22 & 0.879 & 0.042 \\
\hline & 3 & - & -0.37 & 0.41 & - & - & 0.24 & 0.921 & 0.042 \\
\hline & 4 & - & -0.30 & 0.36 & -0.69 & - & 0.25 & 0.945 & 0.024 \\
\hline & 5 & -0.29 & -0.27 & 0.55 & -0.85 & - & 0.24 & 0.964 & 0.019 \\
\hline & & $(-0.18)$ & $(-0.79)$ & $(0.29)$ & $(-0.32)$ & - & $(0.26)$ & & \\
\hline
\end{tabular}

Forward selection stepwise regression $\mathrm{F}$-in $=4.0, \mathrm{~F}$-out $=2.0$

( ) ; Standardized coefficient

ど材歯 7 日の強度発現率は小さくなる。

$\Delta f_{28}$ については、最高温度が最も密接な関係にあり、その影響 も大きいが、最高温度のみを变数とした場合には寄与率が 0.68 と低 く、前盖生時間、後養生温度、温度上昇勾配などを変数に取り込む ことにより、寄与率が 0.90 以上になる。

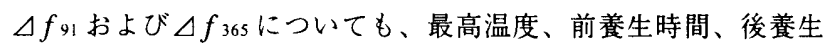
温度、温度上昇勾配および前養生温度を変数に用いることで、寄与 率が高くなる。材㱓28 日、91日および365日では、前養生時間が 短く、前養生温度および最高温度が高く、温度上昇勾配が急激で、 後養生温度が低い条件ほど強度発現率が小さくなることがわかる。 3.4 履歴温度がコンクリートの強度発現に及ぼす影響の時間依存性

3.3 の結果より、コンクリートの強度発現に及ほす高温履歴の影 響は、コンクリートの練上がりを起点とした経過時間によって異な るものと考えられる。そこで、初期材歯を $0 \sim 0.5$ 日，0.5〜 1 日， $1 \sim 2$ 日，2 3 日，3〜5日拈よび 5 日以降の 6 区間に分け、そ れぞれの区間の平均履歴温度と、各材㱓における高温履歴コンク リートと20Sコンクリートの強度発現率の差 $\Delta f_{\mathrm{t}}$ の関係を(7)式で
Table 5 Results of multiple regression analysis

\begin{tabular}{c|ccccccc|c}
\hline$\Delta f_{1}$ & \multicolumn{7}{|c|}{ Coefficient b } & Multiple \\
\cline { 2 - 8 } & $\mathrm{T}^{*} 0-0.5 \mathrm{~d}$ & $\mathrm{~T}^{*} 0.5-1 \mathrm{~d}$ & $\mathrm{~T}^{*}{ }_{1-2 \mathrm{~d}}$ & $\mathrm{~T}^{*}{ }_{2-3 \mathrm{~d}}$ & $\mathrm{~T}^{*}{ }^{3-5 \mathrm{~d}}$ & $\mathrm{~T}^{*}$ 5d- & $\mathrm{R}^{2}$ \\
\hline$\Delta f_{1}$ & 0.19 & 0.42 & - & - & - & - & 0.968 \\
& $(0.21)$ & $(0.79)$ & - & - & - & - & \\
\hline$\Delta f_{3}$ & 0.01 & -0.10 & 0.39 & -0.05 & - & - & 0.816 \\
& $(0.02)$ & $(-0.47)$ & $(1.20)$ & $(-0.09)$ & - & - & \\
\hline$\Delta f_{7}$ & -0.27 & -0.18 & 0.28 & -0.36 & 0.75 & -0.07 & 0.884 \\
& $(-0.59)$ & $(-0.67)$ & $(0.65)$ & $(-0.45)$ & $(0.73)$ & $(-0.06)$ & \\
\hline$\Delta f_{28}$ & -0.49 & -0.09 & -0.04 & -0.20 & 0.64 & 0.27 & 0.935 \\
& $(-0.77)$ & $(-0.24)$ & $(-0.06)$ & $(-0.17)$ & $(0.44)$ & $(0.17)$ & \\
\hline$\Delta f_{91}$ & -0.59 & -0.14 & -0.06 & -0.32 & 0.30 & 0.70 & 0.960 \\
& $(-0.73)$ & $(-0.28)$ & $(-0.07)$ & $(-0.22)$ & $(0.16)$ & $(0.36)$ & \\
\hline$\Delta f_{365}$ & -0.62 & -0.07 & -0.17 & -0.09 & -0.08 & 0.97 & 0.953 \\
& $(-0.78)$ & $(-0.16)$ & $(-0.23)$ & $(-0.06)$ & $(-0.04)$ & $(0.50)$ & \\
\hline
\end{tabular}

( ) ; Standardized coefficient

定義し、その関倸を重回帰分析を用いて検討した。なお、ここでは 20Sコンクリートの温度履歴条件および強度発現率を基準としたた め、各区間の平均履歴温度についても $20^{\circ} \mathrm{C}$ を基準とした(8)式に示 す $T^{*} を$ 重回帰分析に用いた。

$$
\begin{aligned}
\Delta f_{1}=\mathrm{b}_{1} \times \mathrm{T}^{*}{ }_{0-0.5 \mathrm{~d}}+\mathrm{b}_{2} \times \mathrm{T}^{*}{ }_{0.5-1 \mathrm{~d}}+\mathrm{b}_{3} \times \mathrm{T}^{*}{ }_{1-2 \mathrm{~d}} \\
+\mathrm{b}_{4} \times \mathrm{T}^{*}{ }_{2-3 \mathrm{~d}}+\mathrm{b}_{5} \times \mathrm{T}^{*}{ }_{3-5 \mathrm{~d}}+\mathrm{b}_{6} \times \mathrm{T}^{*}{ }_{5 \mathrm{~d}} .
\end{aligned}
$$

なだし、

$$
\mathrm{T}^{*} \mathrm{t}_{1-\mathrm{t} 2}=\mathrm{T}_{\mathrm{t} 1-\mathrm{t} 2-20}
$$

ここに、 $\Delta f_{\mathrm{t}}$ : 高温履歴コンクリートと20Sコンクリートの材齢 $\mathrm{t}$ 日における 強度発現率の差 $(\%)$

$\mathrm{T} \mathrm{t}_{1}-\mathrm{t}_{2}:$ 時間 $\mathrm{t}_{1}$ から $\mathrm{t}_{2}$ にかけ外ての平均履桭温度 $\left({ }^{\circ} \mathrm{C}\right)$

$b_{1}, b_{2}, b_{3}, b_{4}, b_{5}, b_{6}$ : 偏回㷌保数

重回帰分析の結果を Table 5 に示す。なお、Table 5 中の( )内の 数值は標準化回帰係数である。

$\Delta f_{1}$ については、 $0 \sim 0.5$ 日の平均履歴温度に比べて $0.5 \sim 1$ 日 の平均履歴温度の影響が大きく、0.5 1 日の高温履歴は材齢 1 日 までの強度発現を著しく促進させることがわかる。

$\Delta f_{3}$ についは、1～2 日の平均履歴温度の影響が大きく、1 2 日の高温履歴は材龄 3 日での強度発現率を大きくする。逆に、 0.5 〜 1 日の高温履歴は材踰 3 日での強度発現率を小さくする傾向にあ る。

$\Delta f$ については、3～ 5 日の平均履歴温度の影響が大きく、3 5 日の高温履歴は材齢 7 日での強度発現率を大きくする。逆に、0 ～ 0.5 日および $0.5 \sim 1$ 日の高温履歴は材龄 7 日での強度発現率を 小さくする。なお、 $\Delta f_{3}$ および $\Delta f_{7}$ の回㷌方程式については、3.3 において温度履歴要因を変数に用いた場合よりも高い寄与率を示し ており、各区間の平均履歷温度を变数に用いた方が強度発現率を的 確に推定できることがわかる。

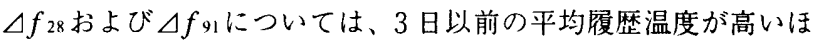
ど強度発現率は小さくなり、逆に、3 日以降の平均履歴温度が高い ほど強度発現率は大きくなる。強度発現率を低下させる要因の中で、 
最も影響が大きいのは 0 - 0.5 日の平均履歴温度であり、次いで 0.5 〜 1 日の平均履歴温度である。すなわち、高温履歴を受ける時期が 早期であるほど、長期材齢での強度発現率の低下が著しいことがわ かる。

$\Delta f_{365}$ については、5 日以前の平均履歴温度が高いほど強度発現 率は小さくなり、逆に、5 日以降の平均履歴温度が高いほど強度発 現率は大きくなる。 $\Delta f_{28}$ および $\Delta f_{91}$ と同様に、0〜0.5 日の平均 履歴温度の影響が著しく、0 0.5 日の平均履歴温度が $1{ }^{\circ} \mathrm{C}$ 高いと 材齢 365 日での強度発現率は約 $0.6 \%$ 小さくなる。また、2 3 日 および 3 ～ 5 日の平均履歴温度の影響は小さい。

以上の通り、コンクリートの強度発現に及はすす履歴温度の影響に は時間依存性があることが明らかになった。高温履歴を受けたコン クリートの強度発現を検討するには、最高温度や前養生時間などの 温度履歴要因をパラメー夕に用いるよりも、履歴温度の影響を材齢 (時間)ごとに区分してパラメー夕に用いる方が汎用性が高いと考え られる。今後は、強度発現に及ほ寸履歷温度の影響を連続的に時間 積分する方向への発展が必要である。

\section{4.まとめ}

高温履歴を受けたコンクリートの強度発現性を検討した結果、以 下のことが明らかとなった。

1) 温度履歴要因の中でも最高温度は強度発現に大きな影響を及ほす 要因である。最高温度が高いほど材齢 1 日での強度は大きいが、 材齢 28 日以降の強度は小さくなる。

2) 前養生時間が強度発現に及ほすす影響は大きい。同じ最高温度で あっても前養生時間が短いほど、すなわち、早期に高温履歴を受 けたコンクリートほど長期的な強度発現は小さい。

3) 前養生温度 (コンクリートの練上がりから 3 時間の温度) が強度 発現に及ほすす影響は小さい。

4) 後盖生温度 (温度下降の終了以後の温度) が強度発現に及ほす影 響は大きい。後養生温度が高いと長期材龄での強度增進を促進さ せ、後養生温度が低いと長期材齢での強度增進を停滞させる。

5) 温度上昇勾配が大きいほど材齢 3 日以降の強度増進が停滞する。 温度下降勾配が強度発現に及はす影響は小さい。

6) 最高温度だけを指標として高温履歴を受けたコンクリートの強度 発現を推定することはできない。しかし、最高温度、前養生時間、 後盖生温度、温度上昇幻配㧍よび前養生温度をパラメー夕に用い れば、強度発現を推定することができる。

7) コンクリートの強度発現に及はす履歴温度の影響には時間依存性 がある。高温履歷を受ける時期が早期であるほど長期的な強度発 現は小さくなる。特に、コンクリートの練上がりょり 0.5 日間の 履歴温度の影響は著しい。

\section{謝辞}

本研究の実施にあたり、前田弘美氏(当時建設省建築研究所)、不 動建設(株) ·宮本鯉輔氏、東洋建設(株). 安田正雪氏、(株)新井組・岩 井信彰氏および東海興業(株)·中川雄二氏にご協力いただきました。 記して感謝の意を表します。
参考文献

1) 杉山 央, 桝田佳寛, 阿部道彦, 安田正雪, 白石清隆，塩見伊津夫：高 強度プレキャストコンクリートの促進盖生条件と強度性状(その１．冬期 実験の計画および温度履歴)，日本建築学会大会学術講演梗概集 A pp.1089-1090, 1993.9

2) 白石清隆，桝田佳寞，阿部道彦，杉山 央，安田正雪，塩見伊津夫：高 強度プレキャストコンクリートの促進盖生条件と強度性状(その2.冬期 実験における強度性状)，日本建築学会大会学術講演梗概集 A, pp.1091 $1092,1993.9$

3) 塩見伊津夫, 森 浩之：高強度コンクリートを用いたプレキャスト柱部 材の製造実験，日本建築学会大会学術講演梗概集 A, pp.1093-1094, 1993.9

4) 黒羽健嗣, 黒岩秀介, 後藤和正ほか：超高強度コンクリートによる PCa 柱の製造実験，日本建築学会大会学術講演梗概集 A，pp.709-710。 1994.9

5) 佐治 昭, 梅本宗宏, 平賀友晃：高層 $\mathrm{RC}$ 造のPCa 部材に用いた高強度 コンクリートの品質, 日本建築学会大会学術講演梗概集A, pp.589.590, 1995.8

6) 寺井靖人，徳永 優，中村敏昭，梅本宗宏，直原克己：高強度プレキャ ストコンクリートの棈造体強度に関する検討, 日本建築学会大会学術講 演梗概集 A, pp.749.750，1996.9

7)杉山 央, 桝田佳寛, 阿部道彦, 前田弘美, 長谷川拓哉：高強度プレキャ ストコンクリート製造時の温度履歴と強度発現性状の関係(その 4.早強 ならびに低発熱型セメントを用いた模擬部材の温度履歴）、日本建築学会 大会学術講演梗概集 A, pp.757·758, 1996.9

8) 前田弘美, 桝田佳寛, 阿部道楌, 杉山 央, 長谷川拓哉: 高強度プレキャ ストコンクリート製造時の温度履歴と強度発現性状の関係(その5.早強 ならびに低発熱型セメントを用いた模擬部材の強度性状)，日本建築学会 大会学術講演梗摡集 A, pp.759.760，1996.9

9) 仕入豊和, 地濃茂雄：コンクリートの初期強度に抢よはす温度条件(20一 $\left.90^{\circ} \mathrm{C}\right)$ の影響, 日本建築学会論文報告集，第 320 号，pp.1-11，1982.10

10)地濃茂雄，杉山 央：マッシブなコンクリートの強度発現傾问（セメ ントの水和熱の蓄積による高温履歴の影響)，日本建築学会構造系論文報 告集, 第 436 号, pp.1-12, 1992.6

11) 地濃茂雄，一仕入豊利：コンクリートの強度発現におよはす温度履歴条 件 $\left(20 \sim 90^{\circ} \mathrm{C}\right)$ の影替，日本建築学会論文報告集，第 337 号, pp.1·11, 1984.3

12) Paul Klieger: Effect of Mixing and Curing Temperature on Concrete Strength, Journal of the American Concrete Institute, pp.1063.1081. 1958.6

13) 宮本鯉輔, 栘田佳寛, 阿部道滚, 杉山 央, 安田正雪: 高強度プレキャ ストコンクリート製造時の温度履歴と強度発現性状の関係(その) 1.初期 温度履歴要因と強度発現性状に関する基䃈的実験),日本建築学会大会学 術講演梗概集 A, pp.713-714, 1994.9

14) 杉山 央, 桝田佳莧, 阿部道彦, 宮本鯉輔, 安田正雪: 高強度プレキャ ストコンクリート製造時の温度履歴と強度発現性状の関係(その 2 .初期 高温履歴の強度発現への影響を予测する関数モデルの提案), 日本建築学 会大会学術講演梗概集 A, pp.715-716，1994.9

15) 高 範勲, 近藤五郎，森田司郎：水和熱による初期高温履歴を考慮し たコンクリートの強度発現則に関する研究, セメント・コンクリート諭 文集，No.46，pp.820·825，1992

16) 紺野弘敦，山田人司：超高強度コンクリートの構造体強度と強度管理 手法について，コンクリートI学年次報告集，Vol.15，No.1，pp.47·50， 1993

17) 田中敏嗣，竹内 良，丸岡正知，富田六郎：初期材䶖に高温履歴を受 けた高強度コンクリートの強度発現性状, コンクリート工学年次報告集, Vol.19, No.1, pp.193-198, 1997

(1998年5月15日原稿受理，1998年7月31日採用決定) 